\section{Contribution of Marijuana Legalization to the U.S. Opioid Mortality Epidemic: Individual and Combined Experience of 27 States and District of Columbia}

\author{
ARCHIE BLEYER, MD ${ }^{\text {a }}$ \\ BRIAN BARNES, CSWA, MAC, CADC III ${ }^{b}$ \\ a Oregon Health and Science University, \\ Portland, OR and \\ McGovern Medical School, Houston, TX \\ ${ }^{\mathrm{b}}$ PhD Student, Integral and Transpersonal \\ Psychology, California Institute of Integral \\ Studies. San Francisco, CA
}

Corresponding Author:

Archie Bleyer, MD, ableyer@gmail.com 2884 NW Horizon Dr., Bend OR 97703

phone: 541-610-4782 fax: 541-617-9259

Running Head:

U.S. opioid epidemic \& marijuana legalization

Keywords:

marijuana protection hypothesis;

U.S. opioid mortality epidemic;

cannabis legalization

Conflicts of Interest:

None known to either author

External Funding: None

\begin{abstract}
Background Prior studies of U.S. states as of 2013 and one state as of 2015 suggested that marijuana availability reduces opioid mortality (marijuana protection hypothesis). This investigation tested the hypothesis with opioid mortality trends updated to 2017 and by evaluating all states and the District of Columbia (D.C.).

Methods Opioid mortality data obtained from the U.S. Centers for Disease Control and Prevention were used to compare opioid death rate trends in each marijuana-legalizing state and D.C. before and after medicinal and recreational legalization implementation and their individual and cumulative aggregate trends with concomitant trends in non-legalizing states. The Joinpoint Regression Program identified statisticallysignificant mortality trends and when they occurred.
\end{abstract}

Results Of 23 individually evaluable legalizing jurisdictions, $78 \%$ had evidence for a statisticallysignificant acceleration of opioid death rates after medicinal or recreational legalization implementation at greater rates than their prelegalization rate or the concurrent composite rate in non-legalizing states. All four jurisdictions evaluable for recreational legalization had evidence $(p<0.05)$ for subsequent opioid death rate increases, one had a distinct acceleration, and one a reversal of prior decline. Since 2009-2012, when the cumulative-aggregate opioid death rate in the legalizing jurisdictions was the same as in the nonlegalizing group, the legalizing group's rate accelerated increasingly faster $(\mathrm{p}=0.009)$. By 2017 it was $67 \%$ greater than in the non-legalizing group $(\mathrm{p}<<0.05)$.

Conclusions The marijuana protection hypothesis is not supported by recent U.S. data on opioid mortality trends. Instead, legalizing marijuana appears to have contributed to the nation's opioid mortality epidemic. 
medRxiv preprint doi: https://doi.org/10.1101/19007393; this version posted October 10, 2019. The copyright holder for this preprint (which was not certified by peer review) is the author/funder, who has granted medRxiv a license to display the preprint in perpetuity. It is made available under a CC-BY-NC 4.0 International license.

\section{Introduction}

According to the Institute for Health Metrics and Evaluation, the United States (U.S.), leads the world in opioid death rate by more than twice that of next closest county [Libya]) and is $2^{\text {nd }}$ worldwide in cannabis use disorder prevalence (Fig. 1). ${ }^{1}$ Are these two dire statistics related, and if so, how?

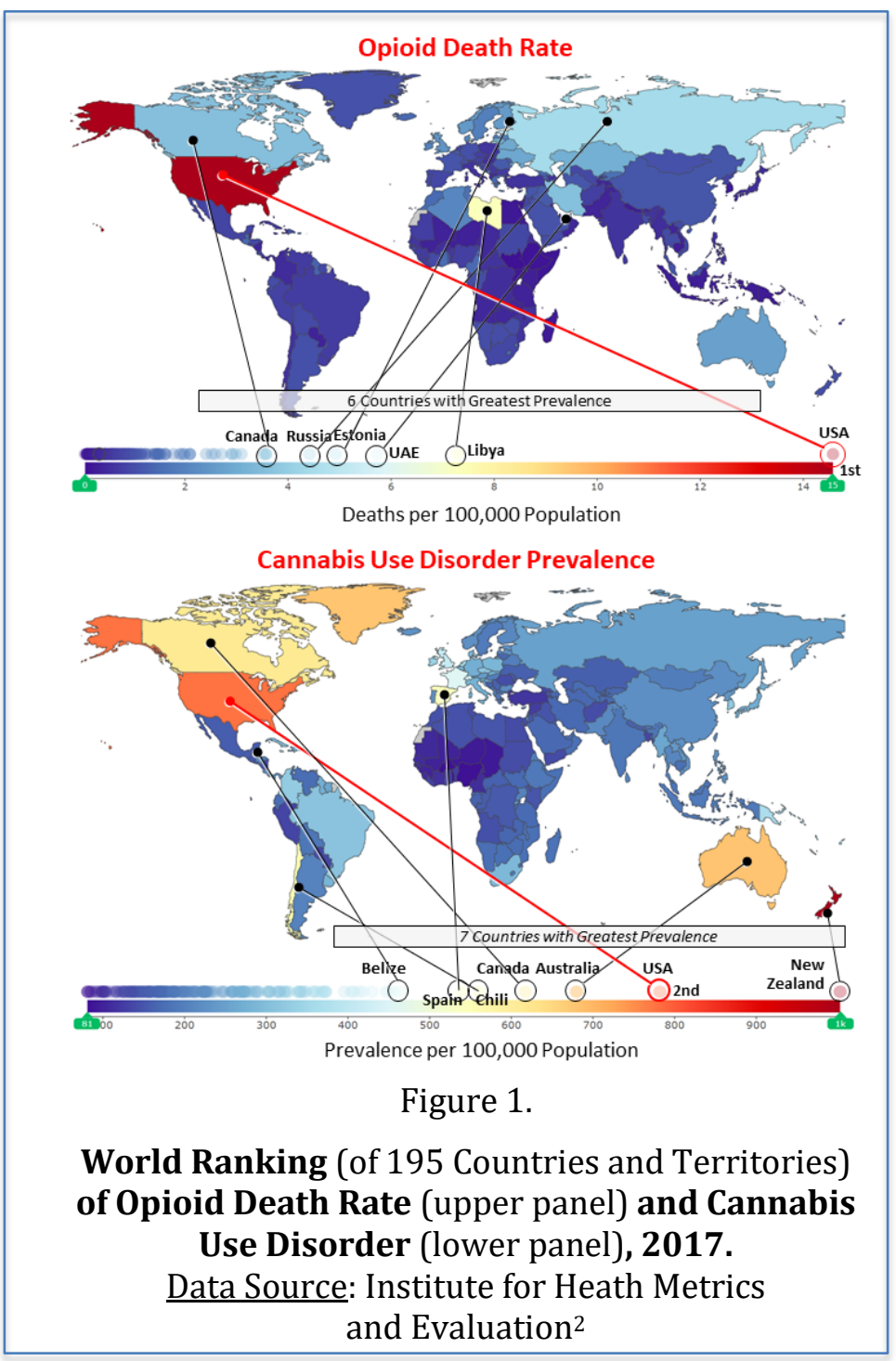

According to data at the U.S. Centers for Disease Control and Prevention, ${ }^{2}$ the U.S.'s national opioid death rate trend since 1999 is directly proportional to the percent of American's able to access marijuana legally ( $p<10^{-10}$, Fig. 2). To what extent is this correlation cause and effect (marijuana use leading to opioid abuse)?

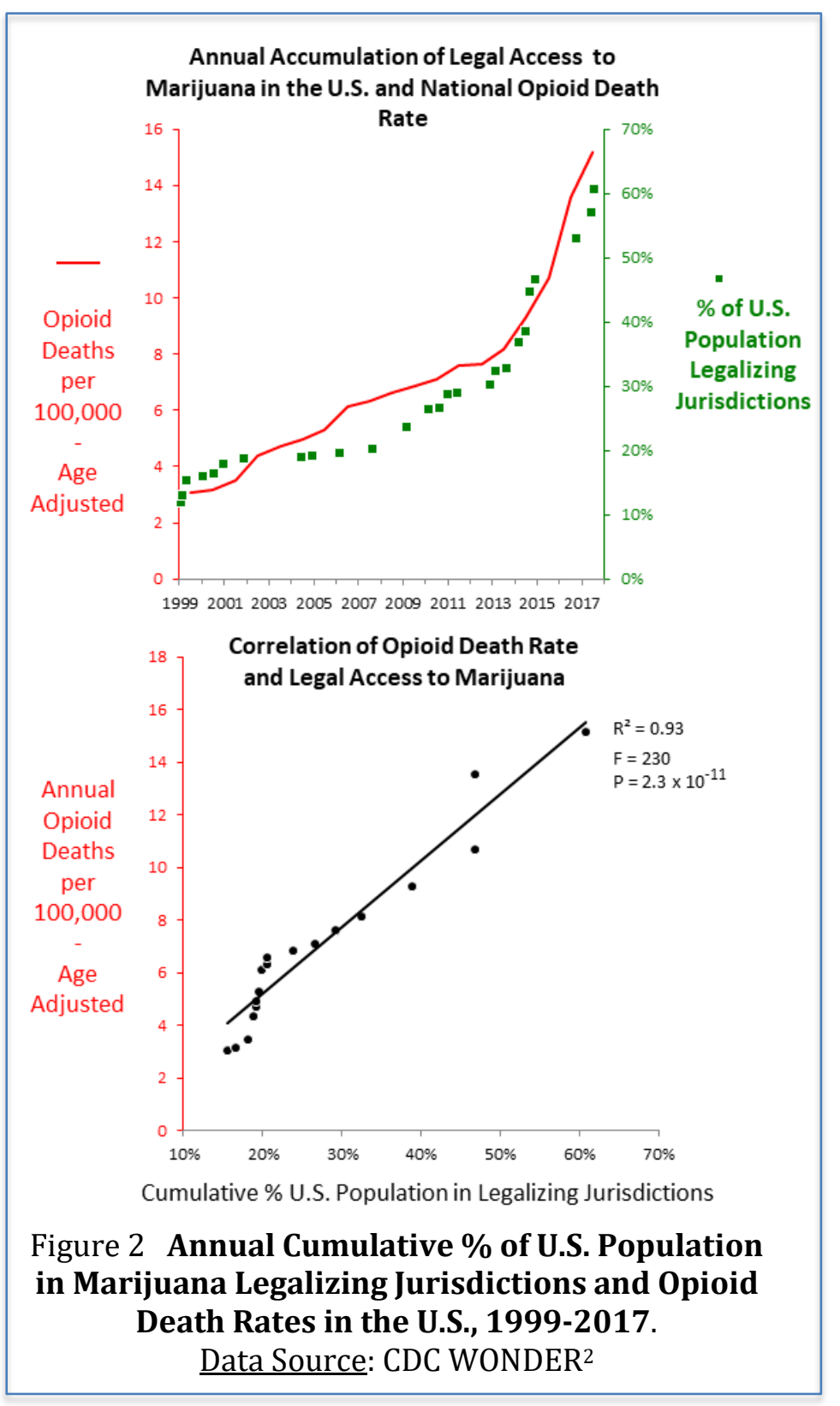

Three prior reports ${ }^{3-5}$ from the U.S. presented data supporting the marijuana protection hypothesis: availability of marijuana reduces deaths from opioids. Bachhuber et $\mathrm{al}^{3}$ analyzed opioid death rates as of 2010 after medicinal marijuana legalization in 10 U.S. states. Powell et $\mathrm{al}^{4}$ extended the opioidrelated mortality analysis to 2013 and added 6 states and the District of Columbia (D.C.) that legalized medicinal marijuana during 2010-2013. Livingston et $\mathrm{al}^{5}$ investigated opioid deaths after recreational legalization in a single state, Colorado, as of December 2015, 24 months after legalization. These authors concluded that cannabis legalization was associated with significantly lower state-level opioid mortality rates ${ }^{3-5}$ and that the reduction represented a reversal of opioid-related death trends. ${ }^{5}$ Although 
neither of the first two reports were claimed to be definitive, editorial commentary ${ }^{6,7}$ and the public response ${ }^{8}$ generally accepted the results as supportive of legalization. Billboards in major U.S. metropolitan communities subsequently claimed "states that legalized marijuana had $25 \%$ fewer opioid related deaths", with reference to the Bachhuber report. ${ }^{9}$

We undertook our study to more adequately test the marijuana protection hypothesis by evaluating all 50 states and D.C., adding six more states that subsequently legalized marijuana, extending the follow-up of all legalizing jurisdictions by four more years, and including the effect of recreational marijuana legalization in three more states. We tested the hypothesis via three comparisons: each legalizing jurisdiction before and after legalization implementation; each legalizing jurisdiction relative to concomitant trends in all non-legalizing states; and the cumulative aggregate of legalizing jurisdictions with concomitant trends in nonlegalizing jurisdictions. The results strengthen a preliminary and partially inaccurate correspondence ${ }^{10}$ and do not support the marijuana protection hypothesis.

\section{Methods}

Mortality data were obtained from the Centers for Disease Control and Prevention (CDC), National Center for Health Statistics CDC WONDER Multiple Cause of Death Files ${ }^{2}$ that provide death data from 1999 to, as of this analysis, 2017. All annual death rates obtained from CDC WONDER were age-adjusted according to the United States 2000 standard population. Rarely, when the CDC database provided the number of deaths and population but not the corresponding death rate, the rate was calculated from the deaths and population data.

Trend analysis was performed with the Joinpoint Regression Program, version 4.6.0.0.11 The Joinpoint Regression Program identifies trend inflections ("joinpoints") to determine when a trend changes to another trend, the probability range of the inflection, and the average annual percent change (AAPC) and $p$ values for each trend detected. It allows statistical significance testing of trend differences and does not depend on parallel trend assumptions. Joinpoint analysis was applied with weighted least squares, Poisson methods, logarithmic transformation, and standard errors.

International Classification of Disease (ICD) $\mathrm{T}$ Codes used for the primary analysis were T40.0 opium, T40.1 heroin, T40.2 other opioids, T40.3 methadone, T40.4 other synthetic opioids, and T40.6 other synthetic narcotics. The opiates include morphine, hydromorphone, oxycodone, fentanyl, semisynthetic fentanyl moieties, heroin, opium, codeine, meperidine, methadone, propoxyphene, tramadol, and other/unspecified narcotics. The $\mathrm{T}$ categories were applied in conjunction with the following ICD codes: X40X44 accidental poisoning, X60-X64 intentional self-poisoning, Y10-Y14 other poisoning.

Table 1 lists each state and D.C. by whether and when marijuana legalization for medicinal or recreational use was implemented. The implementation dates for jurisdictions that legalized before 2015 are those published by Powell et al ${ }^{4}$ and those since were obtained from other sources. ${ }^{12,13}$ The earliest available opioid mortality data on the CDC website is January 1999. One state (California) implemented marijuana legalization 26 months before the first available opioid mortality data (Table 1). The two most recent jurisdictions to legalize marijuana during before December 2017, Ohio and Pennsylvania, did so in April and June of 2016, respectively, but did not implement via state-approved dispensaries for more than a year.

Each legalizing jurisdiction was evaluated individually for opioid mortality trends before and after legalization implementation, if feasible, and in combination with other legalizing jurisdictions in a comparison of all legalizing and nonlegalizing jurisdictions (composite analysis).

Legalizing Jurisdictions Four states were inevaluable for individual trend analysis since they either implemented legalization too early (California) before the available opioid mortality data or too recently (Florida, Ohio, Pennsylvania) to assess their post-implementation opioid mortality trend (Table 1). Excluding these four states, a total of 22 states and D.C. were each evaluable for trend analysis (Table 1). 
For individual jurisdictions (state and D.C.) that legalized marijuana, two comparisons were conducted: 1) the opioid death rate trends before and after legalization implementation and 2) the post-legalization opioid death trend and its statistically significant AAPCs derived with Joinpoint Regression Program ${ }^{11}$ was compared with the composite of non-legalizing states.

Non-Legalizing Jurisdictions The nonlegalizing group consisted of 24 states that had not implemented legalization by December 2017. Georgia was included in the nonlegalizing group since it legalized only CBD oil and only for epilepsy.

The composite of legalizing and non-legalizing groups of jurisdictions were compared with the former aggregated by accumulation of each legalizing jurisdiction when it implemented legalization during 1999 2017, after either medicinal or recreational legalization implementation. Given the relatively few states that legalized marijuana during the early years - nine states during 19962007 - the comparison between the legalizing and non-legalizing groups was regarded not to be meaningful until either the legalizing group rate was stable or both groups has the same rates, both of which occurred during 2009-2011. Because the rates were identical in 2009-2011 and had overlapping $95 \%$ confidence intervals in 2012 , difference-indifference methodology was unnecessary to compare the subsequent trends. Because of delays in implementing medicinal legalization, the two most recent legalizing states, Pennsylvania and Ohio, were both evaluated with, and excluded from, the composite legalizing group.

\section{Results}

Analyses of individual legalization jurisdictions compared with a composite result of non-legalizing jurisdictions are presented first, followed by comparisons of a composite of legalizing jurisdictions with a composite of non-legalizing jurisdictions.

\section{Individual Jurisdiction (State and D.C.) Analysis}

Figure 3 provides the guide to Figures 4, 5 and 6 that depict the annual opioid death rate during 19992017 in each of the individually evaluable 22 legalizing states and D.C. The green and black curves are the $95 \%$ confidence intervals for the legalizing and non-legalizing jurisdictions, respectively. The red and green vertical bars indicate medicinal and recreational legalization implementation, respectively. Each legalizing jurisdiction was assessed both for its opioid death trend compared to the non-legalizing group and for its trend before and after legalization implementation.

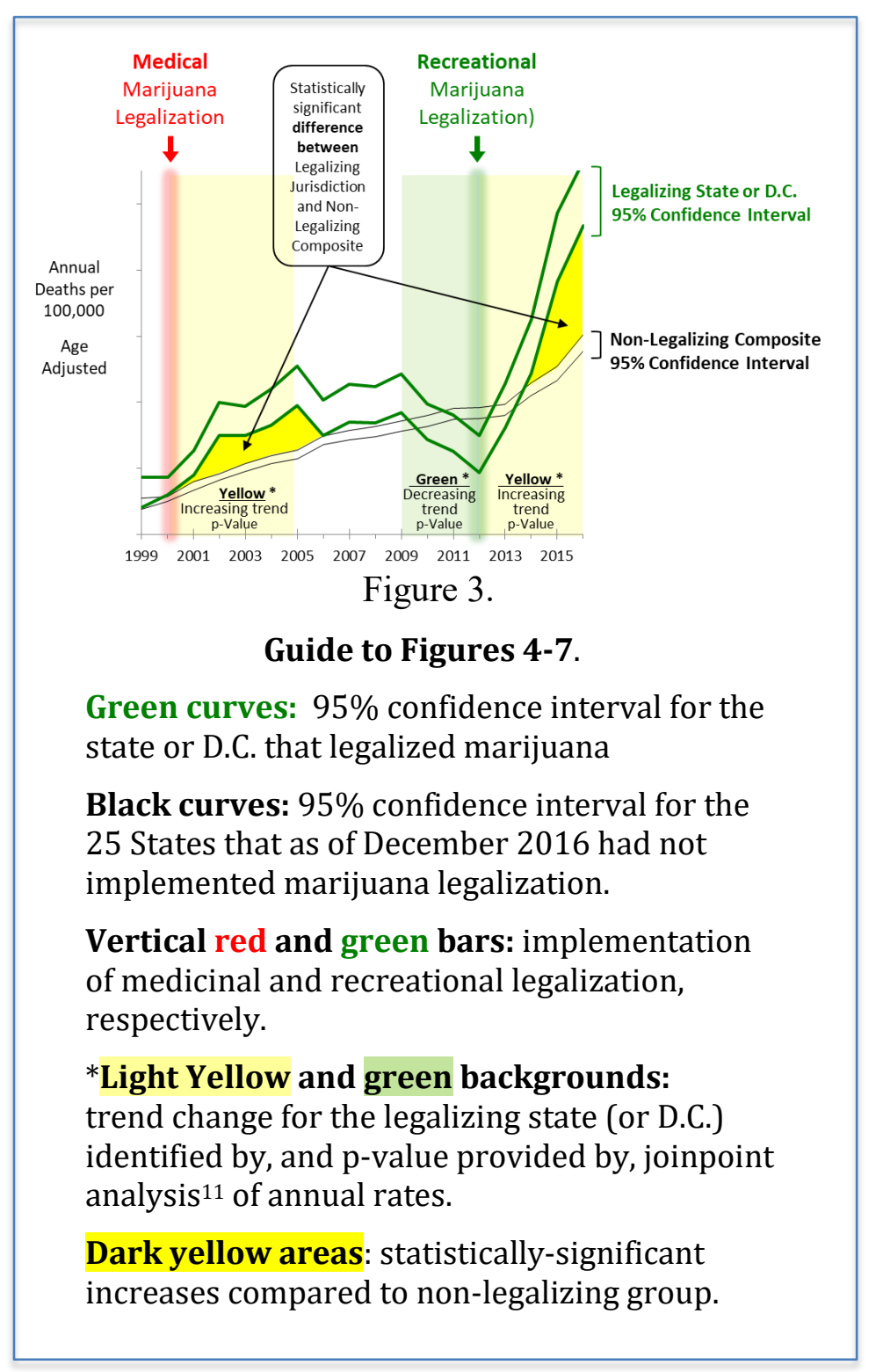




\section{Comparison with Non-Legalizing States}

Of 23 jurisdictions individually evaluable for comparison with the non-legalizing group of jurisdictions (Figs. 4 and 5), 17 (74\%) had statistically-significantly higher opioid death rates after legalization implementation than the non-legalizing group (Fig. 4), as indicated by separation of the $95 \%$ C.I. zones between the legalizing jurisdiction and the non-legalizing group $(\mathrm{p}<0.05)$. Fifteen $(88 \%)$ of the 17 had multiple $95 \%$ C.I. separations between them and the non-legalizing group ( $\mathrm{p}<<0.05)$. Montana had the least degree of separation but the trend thereafter abruptly reversed after medicinal marijuana access in the state was severely limited and the number of medical cardholders plummeted from 31,000 in May 2014 to 9,000 six months later. ${ }^{14}$ Three states (Arizona, Minnesota, New Mexico) had trends that were similar to the non-legalizing group (Fig. 5). Two states that had a delayed reduction in their annual opioid death rate ultimately had lower annual opioid death rates than the non-legalized group of states (Oregon 15 years later, Hawaii 7 years later) (Fig. 5). Alaska had acceleration of its opioid death rate after recreational legalization that was preceded by 5 years of a declining rate (Fig. 5). In total, 18 (78\%) of the evaluable legalizing jurisdictions have evidence for worsening of their opioid death rates than the non-legalizing group.

\section{Comparison of Pre- and Post-Legalization} Trends Four jurisdictions could not be individually compared for post- versus prelegalization trend since they legalized too early (California) or too recently (Florida, Pennsylvania and Ohio) during the available 1999-2017 span of available data (Fig. 6). Of the evaluable 19 jurisdictions, 16 had acceleration after medicinal legalization, within 1 to 2 years in Connecticut, Illinois, Maine, Massachusetts, Maryland, Montana, Nevada, New Jersey, New Hampshire, and New York, and within 3 to 7 years in D.C., Delaware, Michigan, Rhode Island, Vermont and Washington. Maine's acceleration began 2 years after medicinal legalization and again 10 years later. The three states (Arizona, Minnesota, New Mexico) cited above with trends similar to the non-legalizing group also did not appear to have a change in trend before and after legalization implementation. Two states (New Mexico, Arizona) had greater variability after legalization but ultimately assumed the pre-legalization trend. Two states (Oregon, Hawaii) appear to have had a trend reversal after 6 to 9 years 
medRxiv preprint doi: https://doi.org/10.1101/19007393; this version posted October 10, 2019. The copyright holder for this preprint (which was not certified by peer review) is the author/funder, who has granted medRxiv a license to display the preprint in perpetuity. It is made available under a CC-BY-NC 4.0 International license .

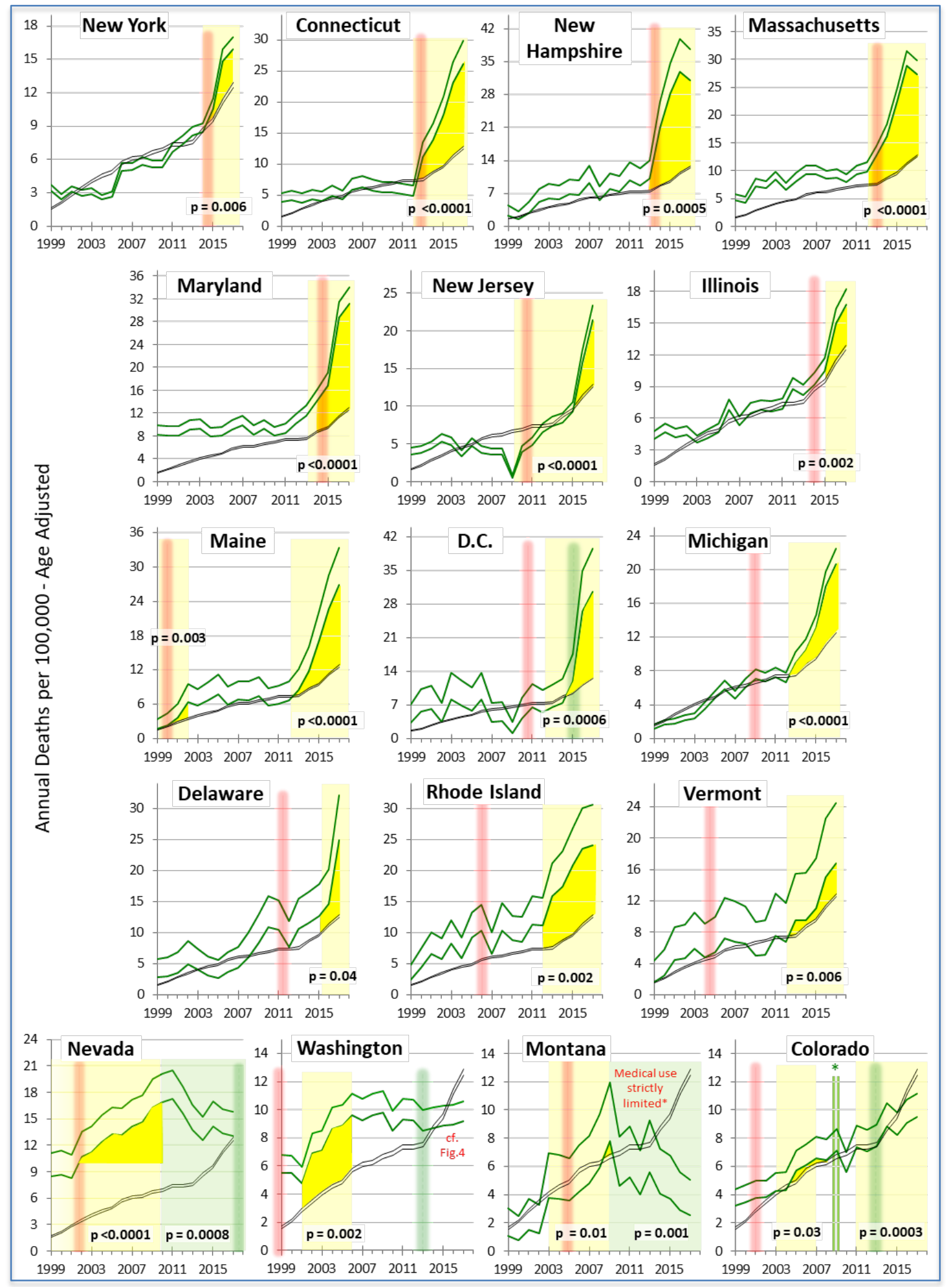

Figure 4. 95\% Confidence Intervals of Annual Opioid Death Rate in Legalizing Jurisdictions with Acceleration of Their Death Rate after Legalization Implementation (green curves) and in Non-Legalizing States Composite (black curves). The jurisdictions are arrayed in order of temporal association of legalization implementation with statistically-significant increase of their subsequent death rate, except for the bottom row which is more multifaceted. The guide to the curves, vertical red and green lines, p-values, background highlighting, and yellow areas is in Figure 3. *In Colorado, several rulings allowed widespread use of marijuana with store front dispensaries across the state and the "Colorado Green Rush". ${ }^{15}$ Data Source: CDC WONDER ${ }^{2}$ 
medRxiv preprint doi: https://doi.org/10.1101/19007393; this version posted October 10, 2019. The copyright holder for this preprint (which was not certified by peer review) is the author/funder, who has granted medRxiv a license to display the preprint in perpetuity.
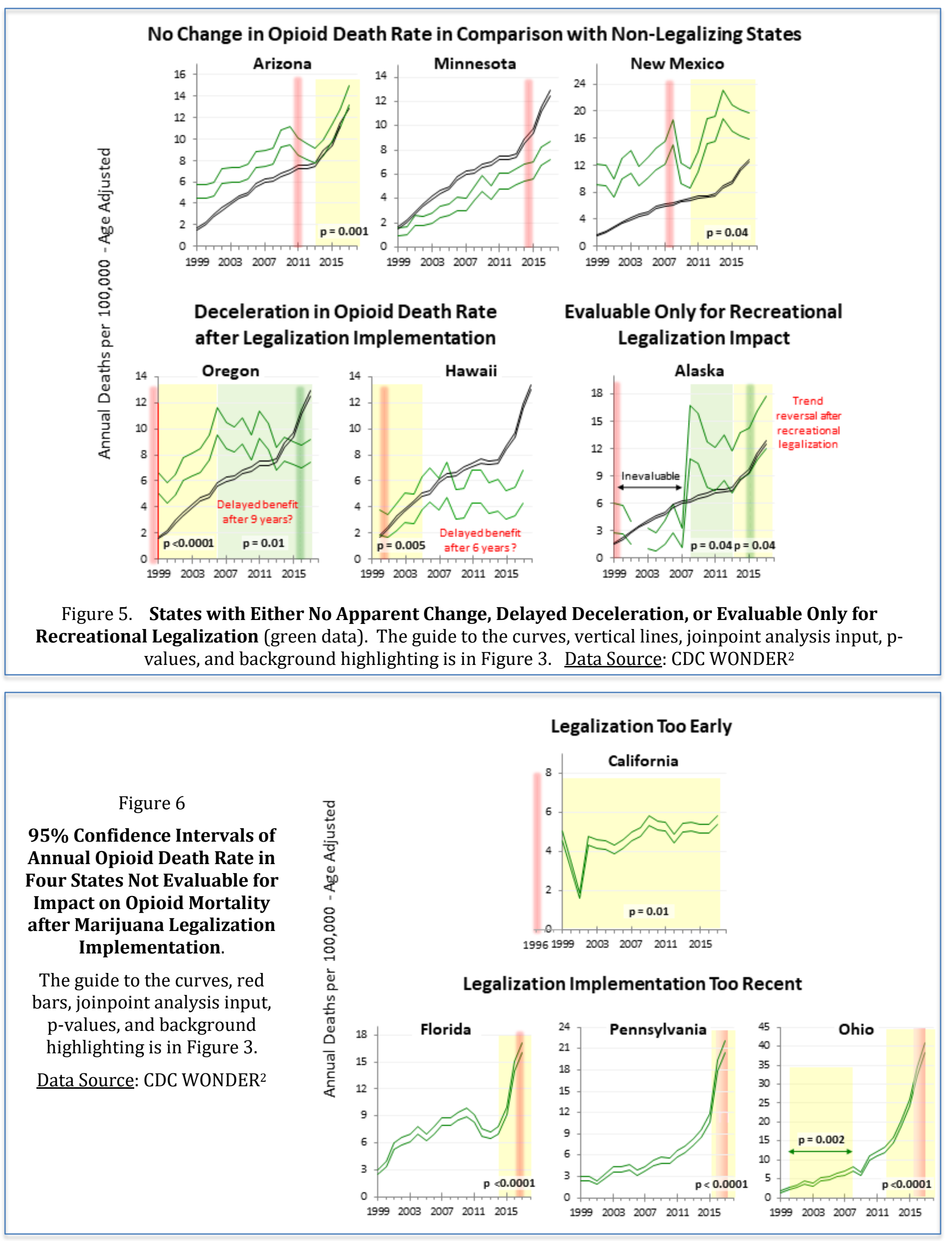


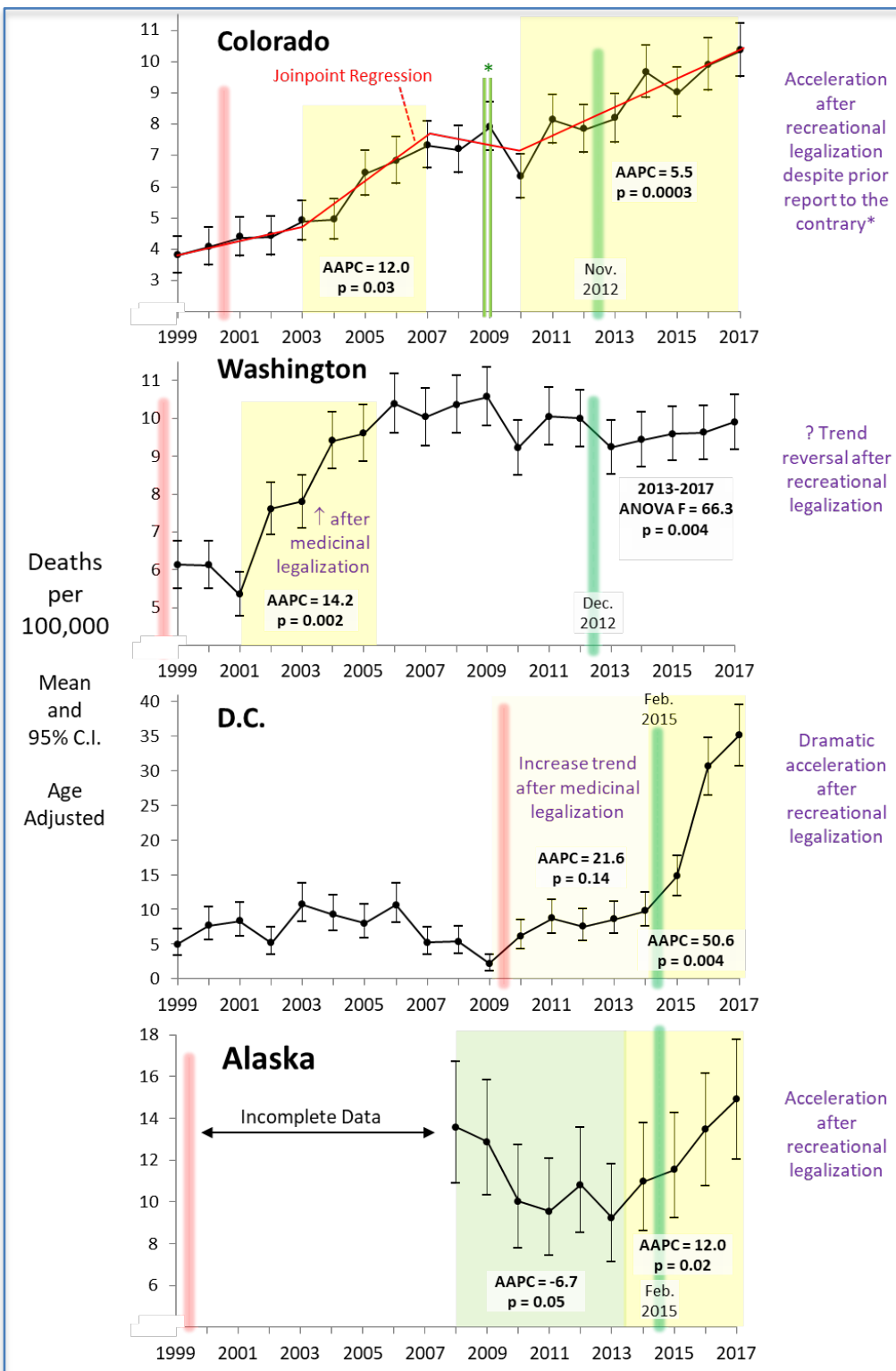

Figure 7.

\section{Mean and 95\% C.I. of Annual Opioid Death Rates in Jurisdictions Evaluable for Impact of Recreational Marijuana Legalization.}

As per Figure 3, vertical bars designate legalization implementation for medicinal (red) and recreational (green) use and colored backgrounds indicate statisticallysignificant trends as determined by Joinpoint regression. *Colorado "Green Rush" 15 is described in Figure 4 legend.

Data Source: CDC WONDER2, Livingston et al. ${ }^{5}$

Figure 7 shows the opioid death rate trends for the four jurisdictions that legalized recreational use and were evaluable for comparison with their recreational pre-legalization trend. After recreational legalization, D.C had a striking acceleration of its opioid death rate (from AAPC of $2.16(\mathrm{p}=0.14)$ to $50.6(\mathrm{p}=0.004)$ and Alaska had reversal of what was a declining trend before recreational legalization to an AAPC of $12.0(\mathrm{p}=0.02)$. Colorado had an increase (AAPC $5.5, \mathrm{p}<0.0003)$ the year after several statewide rulings resulted in widespread use of marijuana ("Colorado Green Rush") with storefront dispensaries throughout the state and protection from federal intervention. ${ }^{15}$ Washington had no significant change, although it has had 4 consecutive years of increase $(p=0.004)$ after a downward trend prior to recreational legalization.

\section{Pre-Legalization and Non-Legalizing Comparisons}

In summary, of the 23 evaluable jurisdictions, 17 states and D.C. (78\%) had a statistically-significant acceleration of their opioid death rates after medicinal or recreational legalization at greater rates than the composite rate in non-legalizing states and/or their pre-legalization rate (Fig. 8). Three states had no change after legalization implementation in comparison with their prelegalization trend or with the composite trend in non-legalizing states. Two states had deceleration of their opioid death rate after legalization implementation and in comparison with the nonlegalizing states, but neither of these had, as of December 2017, statistically-significant lower rates after legalization implementation than before. Of four jurisdictions evaluable for recreational legalization, each had significant $(\mathrm{p}<0.05)$ evidence for subsequent increases in their opioid death rate and two had either a distinct acceleration or reversal of prior decline.

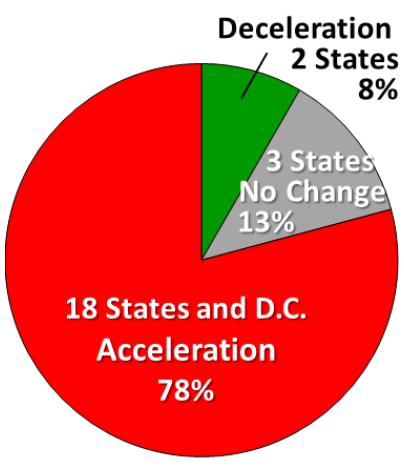

Figure 8.

Summary of 23 Jurisdictions Evaluable for Opioid Death Rate Trend after Marijuana Legalization Implementation, by Trend Trajectory. 
medRxiv preprint doi: https://doi.org/10.1101/19007393; this version posted October 10, 2019. The copyright holder for this preprint (which was not certified by peer review) is the author/funder, who has granted medRxiv a license to display the preprint in perpetuity.

It is made available under a CC-BY-NC 4.0 International license .

\section{Composite Analysis}

Figure 9 shows the annual opioid death rates in legalizing and non-legalizing jurisdiction during 2009-2017, after 12 states had implemented (medicinal) legalization. During 2009-2012, the annual opioid death rate was the same in the nonlegalizing jurisdictions and the cumulative aggregate of the legalizing jurisdictions. The rate increases during 2009-2012 also were the same $($ AAPC $[\mathrm{p}$-value $]=2.1[0.33]$ and $3.6[0.05]$, respectively). Thereafter, the death rate increased one year earlier and more rapidly in the legalizing group. The annual rate during 2015-2017 (AAPC $=24.5, \mathrm{p}=0.04)$ was nearly twice that in the nonlegalizing group $(\mathrm{AAPC}=13.3, \mathrm{p}=0.0001)$ and by 2017 it was $67 \%$ higher than in the non-legalizing group ( $\mathrm{p}<<0.05$ ). The difference between the legalizing and non-legalizing groups for all 9 years during 20092017 was statistically significant $(\mathrm{p}=0.009)$.

From area-under-the-annual-curve analysis of joinpoint regressions, $71 \%$ of the total opioid death rate increase in the U.S. during 2009-2017 occurred in the legalizing jurisdictions. If Pennsylvania and Ohio were excluded from the legalizing group, given that they were the most recent states to legalize and had not fully implemented marijuana availability by the end of 2017, the increase from 2016 to 2017 in the legalizing group was less but still distinctly higher (37\% greater increase as of $2017, \mathrm{p}<<0.05,63 \%$ of 2009-2017 total opioid death rate increase in legalizing jurisdictions).

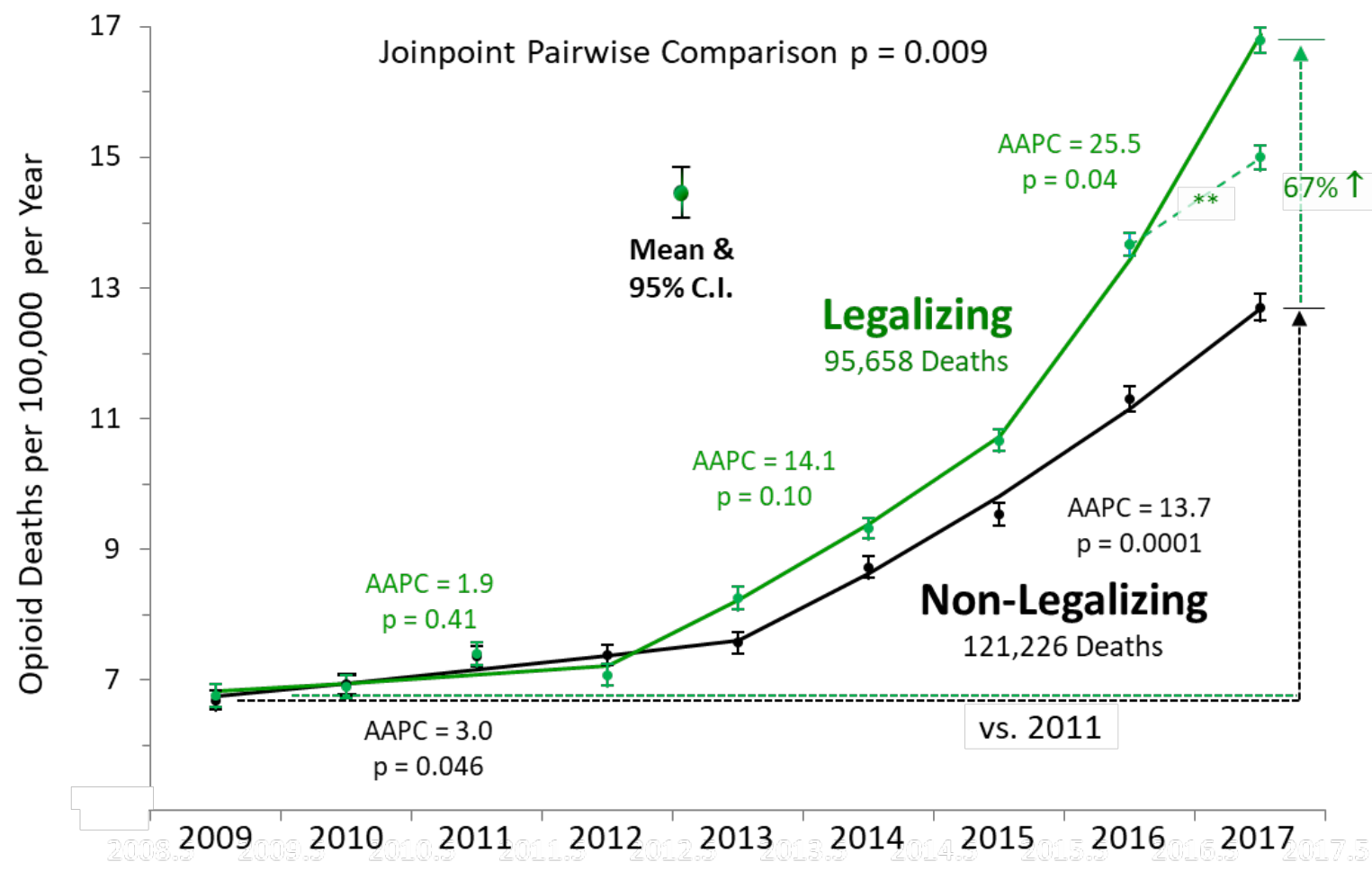

Figure 9.

Joinpoint/AAPC* Analysis of Annual Opioid Death Rates in Non-Legalizing (24 states, black data) and Cumulative Aggregate of Legalizing Jurisdictions (26 states + D.C., green data) during 20092017.

*AAPC - average annual percent change. **Excluding Pennsylvania and Ohio. Data Source: CDC WONDER ${ }^{2}$ 


\section{Discussion}

Note: After this report was submitted for publication, investigators at Stanford University, The Network for Public Health Law, Carrboro, NC New York University, and Center for Innovation to Implementation, Veterans Affairs Health Care System, Palo Alto, has a report published in PNAS with supplementary data the yielded similar results:

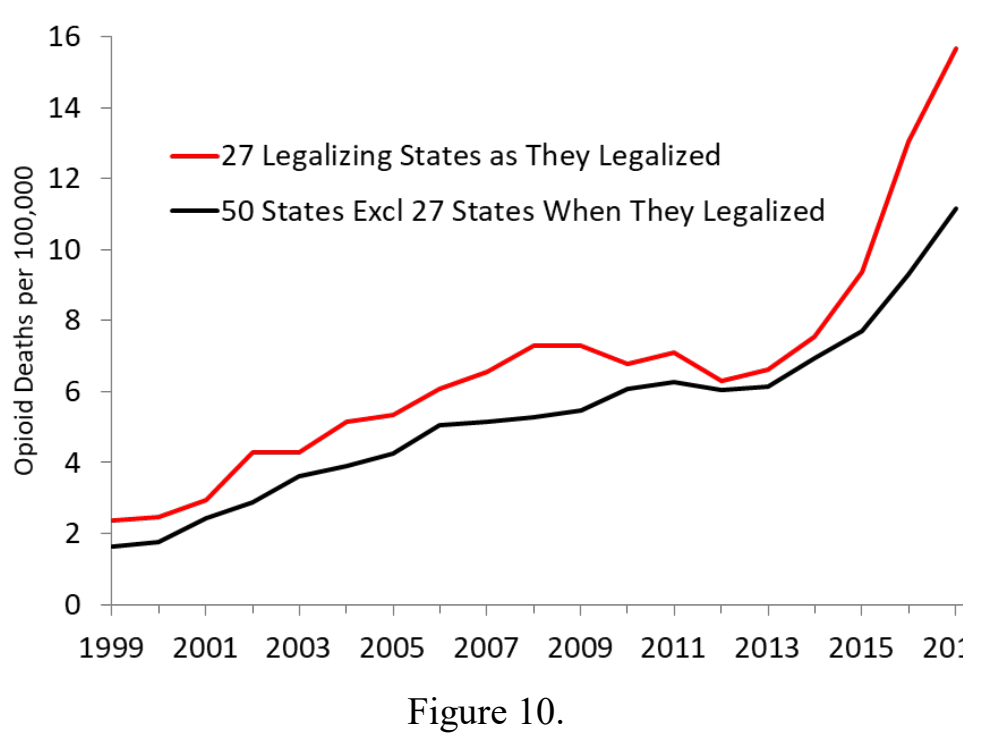

Annual Opioid Death Rate of U.S. States, 1999-2017, by Marijuana Legalization Status

Data Source: Shover CL, Davis CS, Gordon SC, Humphreys K. ${ }^{16}$ Years with $<10$ deaths not included

The divergence in the death rates during 2012-2017 is similar to the separation we observed in Figure 9.

The primary result of their investigation was that association between medical cannabis laws and opioid

Current evidence from the entire U.S., with more states, D.C. and longer follow-up than previously reported, does not support the "marijuana protection" hypothesis. If anything, the evidence presented here suggests the opposite, with $78 \%$ of the evaluable states and D.C. that legalized marijuana having opioid death rate trends consistent in greater increases after legalization than their prelegalization rate or concomitant rate in the nonlegalizing states. Collectively, since 2009-2011 when their rates were the same, the legalizing overdose mortality reversed over time, from a reduction in opioid mortality to an increase that exceeded the opioid death rate prior to marijuana legalization. By 2017 the states that had legalized marijuana had a statistically significant greater increase in opioid death rate than they did before legalization:

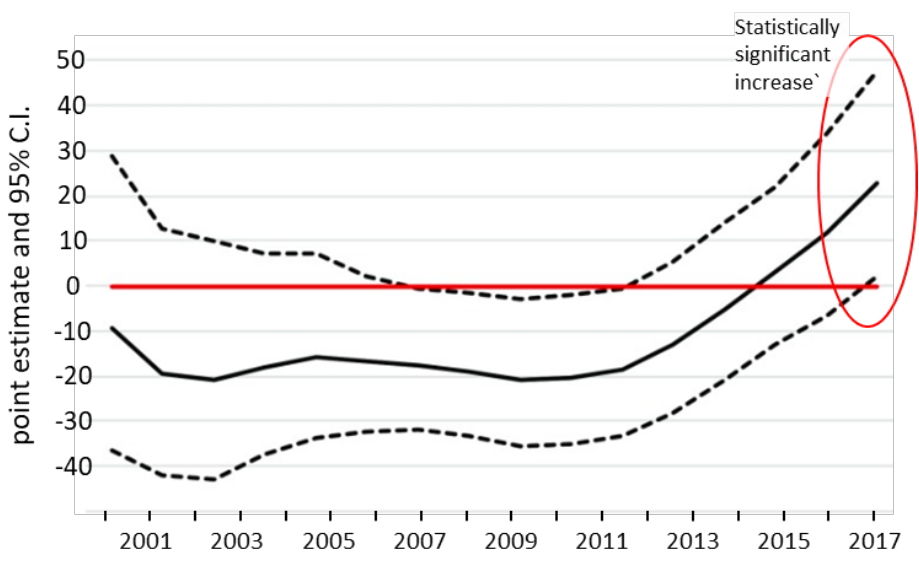

Figure 11.

Annual Changes in Point Estimate and 95\% CI of Association Between Medical Cannabis Law and AgeAdjusted Opioid Overdose Death Rate during 1999-2017.

Fixed (year and state) and time-varying effects with adjustment for prescription drug monitoring program, state unemployment, pain management clinic oversight laws, and prescription drug identification laws.

Source: Modified from Shover CL, Davis CS, Gordon SC, Humphreys K. ${ }^{16}$

The red outline in Figure 11 identifies a statistically significant greater opioid death rate than all previous evaluated years. Our analyses of their results support the findings of our investigation.

jurisdictions have had a highly statisticallysignificant greater increase in their opioid death rate compared to non-legalizing states. The results implicate the jurisdictions that implemented marijuana legalization as accounting for nearly three-fourths of the national opioid death rate during 2009 2017. Overall, the annual national opioid mortality rate was highly correlated with the cumulative proportion of the U.S. population in legalizing jurisdictions ( $\mathrm{p}<10^{-10}$, Fig. 12). 

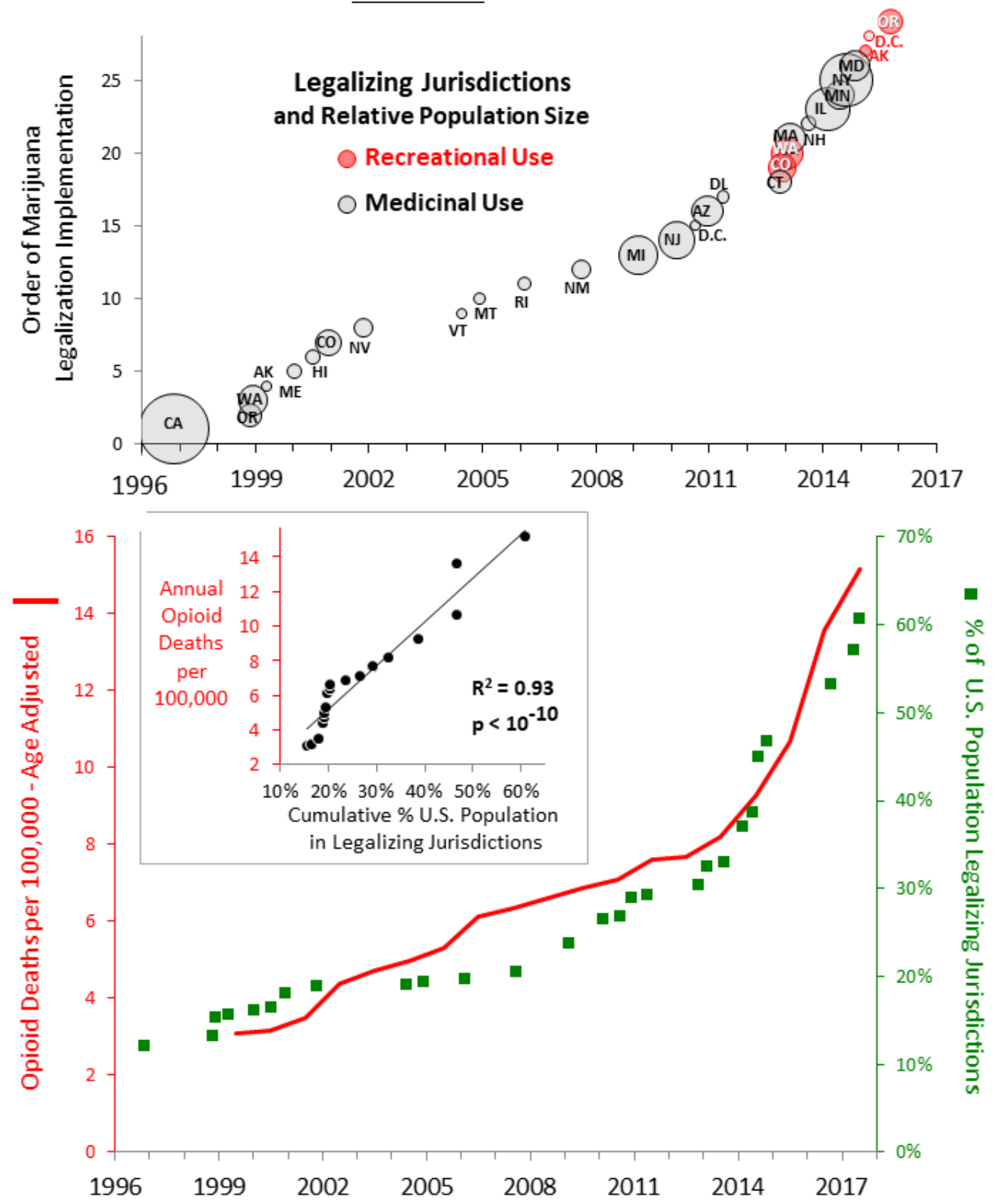

Figure 12. Order of Jurisdiction Legalization (upper panel) and Annual Cumulative Percent of U.S. Population in Marijuana Legalizing Jurisdictions and Opioid Death Rate (lower panel) in the U.S., 19962017, and Correlation of Opioid Death and Cumulative \% of Population in Legalized Jurisdictions

(lower panel inset). Data Source: CDC WONDER ${ }^{2}$

Our investigation has several limitations. Most important, the ecologic design does not establish attribution of causation. Other potential contributing factors other than marijuana legalization that may have resulted in the marijuana legalizing jurisdictions having a higher opioid death rate include strengthening of prescribing laws and regulations in non-legalizing states and the reduction of opioid supply in 20102012 and the invasion of illicitly manufactured fentanyl and fentanyl analogs that started in 2014-
2015 that may have selectively accelerated the transition to heroin in the legalizing jurisdictions. As also noted by Bachhhuber et al, ${ }^{3}$ we could not adjust for differences between states in socioeconomic status, race/ethnicity, or medical and psychiatric diagnoses that may have caused more opioid deaths in the legalizing jurisdictions.

We also could not assess state level variation in the availability of semisynthetic narcotics (fentanyl and analogues) ${ }^{17}$ and of gabapentinoids increasingly being used to potentiate the euphoric 
effect of opioids. ${ }^{18}$ Nor did we assess federal vs. local governmental drug policy, funding, and treatment availability. As emphasized by Pacula et al, ${ }^{19}$ we did not account for state-level access to marijuana due to differences in medical laws across states (qualifying conditions, presence and legal protection of dispensaries, etc.) and recreational laws (passage vs. implementation dates, retailer density, price). With only four evaluable recreational-legalizing jurisdictions, potential differences in the impact of medicinal and recreational legalization could not be quantitated, albeit in the U.S. the degree of overlap between medicinal and recreational cannabis users has been estimated to be $86 \% .{ }^{17}$ Death certificate data may have not correctly classified cases of opioid deaths. With only four evaluable recreational-legalizing jurisdictions, potential differences in the impact of medicinal and recreational legalization could not be quantitated, albeit in the U.S. the degree of overlap between medicinal and recreational cannabis users has been estimated to be nearly $90 \% .{ }^{19}$ We did not use difference-in-difference, interrupted time-series design, or synthetic cohort methodologies applied in prior reports ${ }^{3-5}$ since the legalizing cumulative aggregate and non-legalizing group of jurisdictions had the same rates for three consecutive years during 2009-2011 and statistically similar rates the next year, 2012.

The current investigation also has several advantages over the prior reports. It assesses all states, includes D.C., and evaluates each legalizing jurisdiction both individually and collectively in a cumulative composite aggregate. The individual jurisdiction evaluations include comparisons of post-legalization and pre-legalization trends, comparison of post legalization and non-legalizing jurisdiction composite trends, and both of the aforementioned comparisons. It adds 16 states, D.C., and seven additional follow-up years to the Bachhuber study, ${ }^{3} 10$ more states and four more years to the Powell study, ${ }^{4}$ and two more years to the Livingston srudy. ${ }^{5}$ It evaluates medicinal and recreational legalization effects, both separately and together, whereas both the Bachhuber and Powell studies only assessed medicinal legalization. It evaluates death rates, age-adjusted for annual rates, whereas Livingston et $\mathrm{al}^{5}$ assessed only deaths that were not age-standardized. Although we did not use the difference-indifference methodologies, our selection of joinpoint analysis has the advantages of direct pairwise comparison and identifying when trend changes occur, the probability range of the inflection, and without requiring parallel trend assumptions. We included the T40.6 category of semi-synthetic opioids (including fentanyl and analogues), which had not been coded prior to October $2014^{20}$ and therefore not assessed by Bachhuber et $\mathrm{al}^{3}$ or Powell et $\mathrm{al}^{4}$. We included heroin (T40.1) and opium (T40.0) whereas Bachhuber et $\mathrm{al}^{3}$ did not. (Livingston et $\mathrm{al}^{5}$ did not specify codes they used).

In retrospect, the prior studies were premature assessments. The last year assessed by Bachhuber at $\mathrm{al}^{3}$ was 2010 and by Powell et $\mathrm{al}^{4}$ it was 2013 . Livingston et $\mathrm{al}^{5}$ reported a "reversal of the upward trend in opioid-related deaths" after recreational legalization in Colorado, but assessed the postlegalization trend for just 24 months. Our analysis covers 4 years after recreational legalization during which there is no evidence of a decline in the state's opioid death rate (Fig. 4 upper panel), nor in a 2019 report from the Oregon Department of Public Health and Environment. ${ }^{21}$

If our results indicate that increased availability of marijuana increases opioid use, abuse or overdose potential, this interpretation is consistent with other recent observations. A study conducted by investigators at the National Institute on Drug Abuse, New York State Psychiatric Institute and Columbia University Medical Center concluded that within 3 years of using cannabis, nonmedical prescription opioid use increased 5.8 fold $(95 \%$ $\mathrm{CI}=4.2-7.9)$ and opioid use disorder increased 7.9 fold $(95 \% \mathrm{CI}=5.0-12.3){ }^{22}$ A 4-year prospective cohort study of 1,514 patients with chronic noncancer pain, in whom $24 \%$ used cannabis for pain, those who used cannabis daily or near-daily used more opioids than those who did not (from their data we calculated a $39 \%$ higher oral morphine equivalent consumption, $p=0.0001) .{ }^{23}$ In the an individual-level analysis of a nationally representative sample, medical cannabis use was positively associated with greater use and misuse of prescription opioids. ${ }^{24,25}$ In another study, selfreported marijuana use during injury recovery was 
associated with an increased amount and duration of opioid use. ${ }^{26}$ Conversely, medical prescriptions for Medicaid and Medicare Part D patients have been reported to be associated with reductions in opioid prescribing after legalization. ${ }^{27-30} \mathrm{~A}$ reduction of medical prescriptions for opioids may, however, increase the pursuit of black market opioids of uncertain composition and greater risk. ${ }^{31}$

Behaviorally and socially, marijuana may be a gateway to the use and eventual abuse of opioids and other addicting substances. ${ }^{32-35}$ Biologically, a gateway explanation for the marijuana-opioid connection is plausible since cannabinoids act in part via opioid receptors ${ }^{36,37}$ and increase dopamine concentrations in the nucleus accumbens similarly to that of heroin and related drugs with abuse potential. ${ }^{36,38}$ Clinically, cannabis use may reduce opioid withdrawal symptoms as a "lowefficacy" agent ${ }^{39,40}$ but to date, no prospective evidence, either from clinical trials or observational studies, has demonstrated any benefit of treating patients who have opioid addiction with cannabis. ${ }^{25}$ Cannabis' ameliorating effect may also alleviate opioid withdrawal symptoms and thereby allow opioid use. Legalizing jurisdictions may have a culturally greater affinity for substance use disorder in general and be more vulnerable to gateway mechanisms. Although legalization is expected to decrease illicit activity, the black market may paradoxically benefit from access to more abundant crops, provide lower prices since none of the legalizing jurisdictions have regulated cannabis products, ${ }^{41}$ and by delivering cannabis to users instead of them having to travel to licensed dispensaries.

Trends of individual legalizing jurisdictions and their composite suggest that, if causally related, it initially took several years for legalization implementation to accelerate the opioid mortality rate. As legalization accelerated in the U.S., however, the interval to opioid mortality acceleration appears to have shortened to two years or less (Fig. 12).

A variety of suggestions to reverse the opioid death epidemic have been offered. ${ }^{31,42-66}$ In 2017, the National Academy of Sciences concluded that the myriad of studies of the public impact of cannabis use in all its various forms have not appropriately synthesized, translated for, or communicated to policy makers, health care providers, state health officials, or others responsible for influencing and enacting policies, procedures, and laws related to cannabis use. ${ }^{67}$ A more recent review concluded that recent state regulations that allow medical cannabis as a substitute for opioids for chronic pain and for addiction has at best equivocal evidence regarding safety, efficacy, and comparative effectiveness. 66 The investigators concluded that substituting opioid addiction treatments with cannabis is potentially harmful and does not meet standards of rigor desirable for medical decisions. ${ }^{68}$

Meanwhile, marijuana use and legalization continues to expand. This direction in the U.S., when it leads the world both in cannabis use disorder and in opioid mortality, merits considering marijuana legalization as a contributing factor.

\section{Conclusions}

Population data in the country with the highest prevalence of cannabis use disorder do not support the marijuana protection hypothesis and may indicate the opposite. Recommendations to enact laws to allow medical or recreational cannabis use should not be based on attenuating the opioid crisis. Before other states and countries "rush" to legalize marijuana and risk worsening the opioid crisis, the marijuana-opioid interaction should be more definitively researched.

\section{Acknowledgements}

The authors wish to acknowledge the stress and harm to families and communities caused by addiction. We expect that science-driven clinical understanding and governmental actions will ultimately reduce this burden.

\section{References}

1. Institute for Health Metrics and Evaluation (IHME). GBDCompareDataVisualization. Seattle, WA: IHME, University of Washington, 2016. Available from http:// vizhub.healthdata.org/gbd-compare. (Accessed October 22, 2018).

2. Centers for Disease Control and Prevention, National Center for Health Statistics. Multiple Cause of Death 1999-2016 on CDC WONDER Online Database, released December 2017. Data are from 
the Multiple Cause of Death Files, 1999-2016, as compiled from data provided by the 57 vital statistics jurisdictions through the Vital Statistics Cooperative Program. Accessed at http://wonder.cdc.gov/mcd-icd10.html on Mar 14, 2018.

3. Bachhuber MA, Saloner B, Cunningham, CO, Barry, CL. Medical cannabis laws and opioid analgesic overdose mortality in the United States, 1999-2010. JAMA Intern Med. 2014;174(10):1668-1673. doi:10.1001/jamainternmed.2014.4005. https:// jamanetwork.com/journals/jamainternalmedicine/ful larticle/1898878. Accessed December 27, 2017.

4. Powell D, Pacula RL, Jacobson M. Do medical marijuana laws reduce addictions and deaths related to pain killers? J Health Econ. 2018;58 (March):29-42.

5. Livingston MD, Barnett TE, Delcher C, Wagenaar AC. Recreational cannabis legalization and opioidrelated deaths in Colorado, 2000-2015. Amer J Public Health. 2017;107(11, November 17):1827-1829.

6. Hayes MJ, Brown MS. Legalization of medical marijuana and incidence of opioid mortality. JAMA Intern Med. 2014;174(10):1673-1674. doi:10.1001/jamainternmed.2014.2716.

7. Rogeberg O, Blomkvist AW, Nutt D. Cannabis and opioid overdoses: Time to move on and examine potential mechanisms. Addiction. 2018;113:1551-1552.

8. Ingraham C. Legal marijuana is saving lives in Colorado, study finds. Washington Post. October 16, 2017. https://www.washingtonpost.com/news/wonk/ $\mathrm{wp} / 2017 / 10 / 16 /$ legal-marijuana-is-saving-lives-incolorado-study-finds/?utm_term $=.51 \mathrm{c} 8 \mathrm{ce} 249635$. Accessed December 27, 2017.

9. Hahn E. Verify: Do states that legalize marijuana have $25 \%$ fewer opioid deaths? http://www.kgw.com/article/news/local/verify/verify -do-states-that-legalize-marijuana-have-25-feweropioid-deaths/283-482234472. Accessed March 5, 2018.

10. Bleyer A, Barnes B. Opioid death rate acceleration in jurisdictions legalizing marijuana use. JAMA Int Med. 2018;178(9 Sept):1280-1281.

11. Joinpoint Regression Program, Version 4.6.0.0. April, 2018; Statistical Research and Applications Branch, National Cancer Institute. Statistical Research and Applications Branch, National Cancer Institute. Kim HJ, Fay MP, Feuer EJ, Midthune DN. Permutation tests for joinpoint regression with applications to cancer rates. Stat Med 2000;19:335351 (correction: 2001;20:655).
12. Legality of cannabis by U.S. jurisdiction. https://en.wikipedia.org/wiki/Legality_of_cannabis by_U.S._jurisdiction. Accessed February 28, 2018.

13. Cannabis in [name of state], https://en.wikipedia.org/wiki/Cannabis_in_[name of state]. Accessed October 10, 2018.

14. Cannabis in Montana. https://en.wikipedia.org/wiki/Cannabis_in_Montana. Accessed October 19, 2018.

15. The legalization of marijuana in Colorado: The Impact. Vol. 2. August 2014.

https://www.in.gov/ipac/files/August_2014_Legaliz ation_of_MJ_in_Colorado_the_Impact(1).pdf. Accessed October 8, 2019

16. Shover CL, Davis CS, Gordon SC, Humphreys K. Association between medical cannabis laws and opioid overdose mortality has reversed over time. Proc Natl Acad Sci U S A. 2019 Jun 25;116(26):12624-12626.

17. Pacula RL, Powell D, Heaton P, Sevigny EL Assessing the effects of medical marijuana laws on marijuana use: the devil is in the details. J Policy Anal Manage. 2015 Winter;34(1):7-31.

18. Jannetto PJ, Helander A, Garg U, Janis GC, Goldberger B, Ketha H. The fentanyl epidemic and evolution of fentanyl analogs in the United States and the European Union. Clin Chem. 2018 Oct 10. pii: clinchem.2017.281626. doi: 10.1373/clinchem.2017.281626

19. Evoy KE, Morrison MD, Saklad SR. Abuse and misuse of pregabalin and gabapentin. Drugs. 2017 Mar;77(4):403-426. doi: 10.1007/s40265-017-0700-x.

20. 2018/2019 ICD-10-CM Diagnosis Code T40.6. https://www.icd10data.com/ICD10CM/Codes/S00T88/T36-T50/T40-/T40.6. Accessed October 20, 2018.

21, HealthWatch No. 106. Drug Overdose Deaths in Colorado. Final data for 1999-2017. Registries and Vital Statistics Branch, Center for Health and Environmental Data, Colorado Department of Public Health and Environment. www.colorado.gov/pacific/cdphe/vital-statisticsprogram http://drive.google.com/file/d/1w9pmIXJfMxxPBQc 9KmYoHb_LH0sq0J_o/view? usp=sharing Accessed February $1 \overline{4}, 2019$.

22. Olfson M, Wall MM, Liu SM, Blanco C. Cannabis use and risk of prescription opioid use disorder in the United States. Am J Psychiatry. 2018 Jan 1;175(1):47-53. doi: 10.1176/appi.ajp.2017. 17040413. Epub 2017 Sep 26.

23. Campbell G, Hall WD, Peacock A, et al. Effect of cannabis use in people with chronic non-cancer pain prescribed opioids: findings from a 4-year 
prospective cohort study. Lancet Public Health. 2018 (July);3:e341-350.

24. Caputi TL, Humphreys K. Medical marijuana users are more likely to use prescription drugs medically and non-medically. J Addict Med. 2018;12(4):295299. doi:10.1097/ADM.

25. Humphreys K, Saitz R. Should physicians recommend replacing opioids with cannabis? JAMA. Published online February 1, 2019. doi:10.1001/jama.2019.0077.

26. Bhashyam, AR Heng Marilyn, Harris MB, Vrahas MS, Weaver MJ. Self-reported marijuana use is associated with increased use of prescription opioids following traumatic musculoskeletal injury. J Bone Joint Surg, 2018 (Dec 19);100 (24):2095-2102.

27. Wen H, Hockenberry JM. Association of medical and adult-use marijuana laws with opioid prescribing for Medicaid enrollees. JAMA Intern Med.

Published online April 2, 2018. doi:10.1001/jamainternmed.2018.1007.

28. Liang D, Bao Y, Wallace M, Grant I, Shi Y. Medical cannabis legalization and opioid prescriptions: Evidence on US Medicaid enrollees during 19932014. Addiction. 2018 Jul 10. doi: 10.1111/add.14382.

29. Bradford AC, Bradford WD, Abraham A, Bagwell Adams G. Association between US state medical cannabis laws and opioid prescribing in the Medicare Part D population. JAMA Intern Med. 2018 May 1;178(5):667-672.

30. Shia S, Lianga D, Bao Y, et al. Recreational marijuana legalization and prescription opioids received by Medicaid enrollees. Drug Alcohol Dependence. 2019 (Jan 1);196:13-19.

31. Manchikanti L, Sanapati J, Benyamin RM, Atluri S, Kaye AD, Hirsch JA Reframing the prevention strategies of the opioid crisis: Focusing on prescription opioids, fentanyl, and heroin epidemic. Pain Physician. 2018 Jul;21(4):309-326.

32. Volkow ND, Baler RD, Compton WM, Weiss SR. Adverse health effects of marijuana use. N Engl J Med. 2014;370(23):2219-2227.

33. Lynskey MT, Heath AC, Bucholz KK, et al. Escalation of drug use in early-onset cannabis users vs co-twin controls. JAMA. 2003;289(4):427-433.

34. Yamaguchi K, Kandel DB. Patterns of drug use from adolescence to young adulthood, III: predictors of progression. Am J Public Health. 1984;74(7):673-681.

35. Fergusson DM, Horwood LJ. Early onset cannabis use and psychosocial adjustment in young adults. Addiction. 1997;92(3):279-296.

36. Tanda G, Pontieri FE, Di Chiara G. Cannabinoid and heroin activation of mesolimbic dopamine transmission by a common $\mu 1$ opioid receptor mechanism. Science. 1997;276(5321):2048-2050.

37. Scavone JL, Sterling RC, Van Bockstaele EJ. Cannabinoid and opioid interactions: implications for opiate dependence and withdrawal. Neuroscience. 2013;248:637-654.

38. Ashton $\mathrm{CH}$. Pharmacology and effects of cannabis: a brief review. Br J Psychiatry. 2001;178:101-106.

39. Hermann D, Klages E, Welzel H, Mann K, Croissant B. Low efficacy of non-opioid drugs in opioid withdrawal symptoms. Addict Biol. 2005;10(2):165-169.

40. Scavone JL, Sterling RC, Weinstein SP, Van Bockstaele EJ. Impact of cannabis use during stabilization on methadone maintenance treatment. Neuroscience. 2013;248:637-654.

41. Jensen EL, Roussell A. Field observations of the developing legal recreational cannabis economy in Washington State. Int J Drug Policy. 2016 Jul;33:96-101.

42. Blendon RJ, Benson JM. The public and the opioidabuse epidemic. N Engl J Med. 2018 Feb 1;378(5):407-411. Epub 2018 Jan 3.

43. Bates M.Tackling an epidemic: New and emerging opioid addiction treatments offer hope for solutions to this crisis. IEEE Pulse. 2018 Mar-Apr;9(2):22-25.

44. Lembke A, Humphreys K. The opioid epidemic as a watershed moment for physician training in addiction medicine. Acad Psychiatry. 2018 Apr;42(2):269-272.

45. Jette AM. Responding to the opioid epidemic in the United States. Phys Ther..2018;98(3):147-148.

46. Srivastava AB, Gold MS. Beyond supply: How we must tackle the opioid epidemic. Mayo Clin Proc. 2018 Mar;93(3):269-272.

47. Hays GP, Mycyk MB. Confronting the opioid crisis by taking a long look in the mirror... and at our peers. Acad Emerg Med. 2018 Mar 2. doi: 10.1111/acem.13397. [Epub ahead of print]

48. Haffajee RL, Mello MM. Drug companies' liability for the opioid epidemic. N Engl J Med. 2017 Dec 14;377(24):2301-2305.

49. Barnett ML, Gray J, Zink A, Jena AB. Coupling policymaking with evaluation - the case of the opioid crisis. N Engl J Med. 2017 Dec 14;377(24):2306-2309.

50. Rutkow L, Vernick JS. Emergency legal authority and the opioid crisis. N Engl J Med. 2017 Dec 28;377(26):2512-2514.

51. Glod SA.The other victims of the opioid epidemic. N Engl J Med. 2017 Jun 1;376(22):2101-2102.

52. Psaty BM, Merrill JO. Addressing the opioid epidemic - opportunities in the postmarketing setting. NEngl J Med. 2017 Apr 20;376(16):1502-1504. 
53. Friedmann PD, Andrews CM, Humphreys K. How ACA repeal would worsen the opioid epidemic. N Engl J Med. 2017 Mar 9;376(10):e16.

54. Murthy VH. Ending the opioid epidemic - a call to action. N Engl J Med. 2016 Dec 22;375(25):2413-2415.

55. Williams AR, Bisaga A. From AIDS to opioids how to combat an epidemic. N Engl J Med. 2016 Sep 1;375(9):813-815.

56. Volkow ND, Frieden TR, Hyde PS, Cha SS. Medication-assisted therapies--tackling the opioidoverdose epidemic. N Engl J Med. 2014 May 29;370(22):2063-2066.

57. Edelman EJ, Fiellin DA. Can primary care practices help address the health crisis fueled by prescription opioids? Ann Intern Med. 2017; 166(4):307-308.

58. deShazo R, Johnson M, Eriator I, Rodenmeyer K. Backstories on the U.S. opioid epidemic good intentions gone bad, an industry gone rogue and watch dogs gone to sleep. Am J Med. 2018 Jan 31. pii: S0002-9343(18)30084-6. [Epub ahead of print]

59. Seymour RB, Ring D, Higgins T, Hsu JR. Leading the way to solutions to the opioid epidemic: AOA critical issues. J Bone Joint Surg Am. 2017 Nov 1;99(21):e113.

60. Ballantyne JC. Opioids for the treatment of chronic pain: mistakes made, lessons learned, and future directions. Anesth Analg. 2017 Nov;125(5):17691778.

61. Soelberg CD, Brown RE Jr, Du Vivier D, Meyer JE, Ramachandran BK. The US opioid crisis: current federal and state legal issues. Anesth Analg. 2017 Nov;125(5):1675-1681.

62. Clark DJ, Schumacher MA. America's opioid epidemic: supply and demand considerations. Anesth Analg. 2017 Nov;125(5):1667-1674.

63. Levin FR, Bisaga A, Sullivan MA, Williams AR, Cates-Wessel K. A review of a national training initiative to increase provider use of MAT to address the opioid epidemic. Am J Addict. 2016 Dec;25(8):603-609.

64. Webster LR, Markman J, Cone EJ, Niebler G. Current and future development of extended-release, abuse-deterrent opioid formulations in the United States. Postgrad Med. 2017 Jan;129(1):102-110. Epub 2016 Dec.. Erratum in: Postgrad Med. 2017 May;129(4):491.

65. Mitchell KD, Higgins LJ. Combating opioid overdose with public access to naloxone. J Addict Nurs. 2016 Jul-Sep;27(3):160-179.

66. Wolfe S, Bouffard DL, Modesto-Lowe V. The opioid crisis and the physician's role in contributing to its resolution: step one--prevention of overdoses. Conn Med. 2016 Jun-Jul;80(6):325-334.

67. The health effects of cannabis and cannabinoids: The current state of evidence and recommendations for research (2017). National Academy of Sciences. https://www.nap.edu/catalog/24625/the-healtheffects-of-cannabis-and-cannabinoids-the-currentstate. Accessed July 20, 2018. 
medRxiv preprint doi: https://doi.org/10.1101/19007393; this version posted October 10, 2019. The copyright holder for this preprint (which was not certified by peer review) is the author/funder, who has granted medRxiv a license to display the preprint in perpetuity.

It is made available under a CC-BY-NC 4.0 International license.

\section{Table 1. State and D.C. Marijuana Use Legalization Status and Legalization Implementation Date}

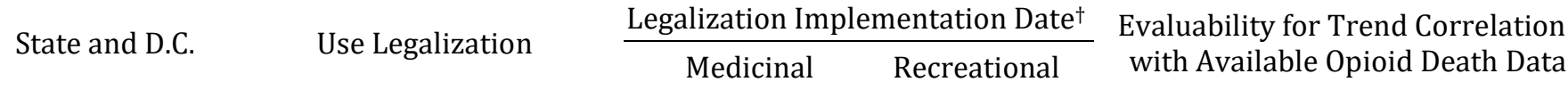

\begin{aligned} \hline & \\ 1 & California \\ 2 & Oregon \\ 3 & Washington \\ 4 & Alaska \\ 5 & Maine \\ 6 & Hawaii \\ 7 & Colorado \\ 8 & Nevada \\ 9 & Vermont \\ 10 & Montana \\ 11 & Rhode Island \\ 12 & New Mexico \\ 13 & Michigan \\ 14 & New Jersey \\ 15 & D.C. \\ 16 & Arizona \\ 17 & Delaware \\ 18 & Connecticut \\ 19 & Massachusetts \\ 20 & New Hampshire \\ 21 & Illinois \\ 22 & Minnesota \\ 23 & New York \\ 24 & Maryland \\ 25 & Pennsylvania \\ 26 & Ohio \end{aligned}

\section{Legalizing States and D.C.}

\begin{tabular}{ccc} 
Medicinal and recreational & $11 / 5 / 1996^{3}$ & $1 / 1 / 2018$ \\
Medical and recreational & $12 / 3 / 1998^{4}$ & $1 / 1 / 2017$ \\
Medicinal and recreational & $12 / 3 / 1998^{3}$ & $12 / 6 / 2012$ \\
Medicinal and recreational & $3 / 4 / 1999^{3}$ & $2 / 24 / 2015$ \\
Medicinal and recreational & $12 / 23 / 1999^{3}$ & $5 / 1 / 2018$ \\
Medicinal only & $6 / 16 / 2000^{3}$ & \\
Medicinal and recreational & $12 / 28 / 2000^{3}$ & $11 / 6 / 2012 \ddagger$ \\
Medicinal and recreational & $10 / 1 / 2001^{3}$ & $7 / 1 / 2017$ \\
Medicinal only & $7 / 1 / 2004^{3}$ & \\
Medicinal only & $11 / 2 / 2004^{3}$ & \\
Medicinal only & $1 / 3 / 2006^{3}$ & \\
Medicinal only & $7 / 1 / 2007^{3}$ & \\
Medicinal only & $12 / 4 / 2008^{3}$ & \\
Medicinal only & $6 / 1 / 2010^{3}$ & $2 / 26 / 2015$ \\
Medicinal and recreational & $7 / 27 / 2010^{3}$ & \\
Medicinal only & $11 / 29 / 2010^{3}$ & 2017 \\
Medicinal only & $5 / 13 / 2011^{3}$ & \\
Medicinal only & $10 / 1 / 2012^{3}$ & \\
Medicinal and recreational & $1 / 1 / 2013^{3}$ & $7 / 2018$ \\
Medicinal only & $7 / 23 / 2013^{3}$ & \\
Medicinal only & $1 / 1 / 2014^{3}$ & \\
Medicinal only & $5 / 30 / 2014^{3}$ & \\
Medicinal only & $7 / 1 / 2014^{3}$ & \\
Medicinal only & $6 / 1 / 2014^{* *}$ & \\
Medicinal only & $4 / 17 / 2016$ & \\
Medicinal only & $6 / 8 / 2016$ & \\
\hline
\end{tabular}
Medicinal only but limited* Medicinal only
Medicinal \& recreational
Medicinal only

Medicinal \& recreational Medicinal only

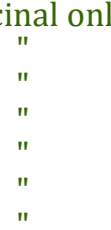

Medicinal \& recreational

Medicinal only

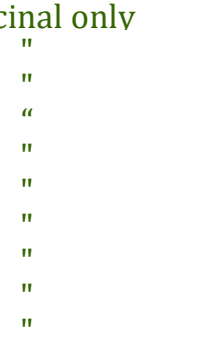

\section{Non-Legalizing States}

$\begin{array}{ll}1 & \text { Georgia } \\ 2 & \text { Florida } \\ 3 & \text { Arkansas } \\ 4 & \text { North Dakota } \\ 5 & \text { West Virginia } \\ 6 & \text { Louisiana } \\ 7 & \text { Alabama } \\ 8 & \text { Idaho } \\ 9 & \text { Indiana } \\ 10 & \text { Iowa } \\ 11 & \text { Kansas } \\ 12 & \text { Kentucky } \\ 13 & \text { Mississippi } \\ 14 & \text { Missouri } \\ 15 & \text { Nebraska } \\ 16 & \text { North Carolina } \\ 17 & \text { Oklahoma } \\ 18 & \text { South Carolina } \\ 19 & \text { South Dakota } \\ 20 & \text { Tennessee } \\ 21 & \text { Texas } \\ 22 & \text { Utah } \\ 23 & \text { Virginia } \\ 24 & \text { Wisconsin } \\ 25 & \text { Wyoming }\end{array}$

Medicinal only Medicinal only Medicinal only Medicinal only Medicinal only Medicinal only
$4 / 16 / 2015$
$11 / 2016$
$11 / 8 / 2016$
$11 / 8 / 2016$
$7 / 2018$

Minimal legalization^ Evaluable End of 2016; Fully Evaluable

Fully Evaluable

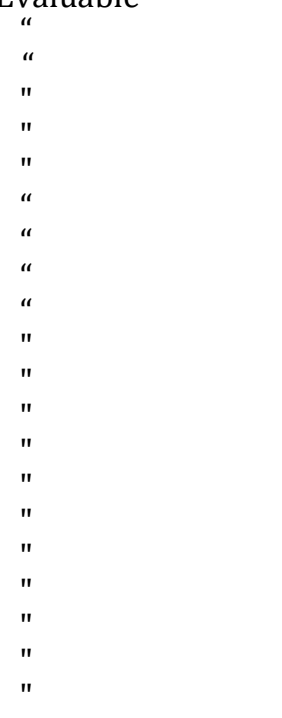

+Source either Powell et al $^{3}$ or Wikipedia ${ }^{12,13}$ * Legalization implementation $>2$ years before $1^{\text {st }}$ available opioid mortality data ${ }^{\ddagger} 2009$ rulings enabled widespread use ${ }^{15} * * 2003$ legislation enabled in $2014^{3}{ }^{\wedge}$ CBD oil for epilepsy ${ }^{\wedge} 2015$ legislation enabled in 2018 